Jurna I I miah

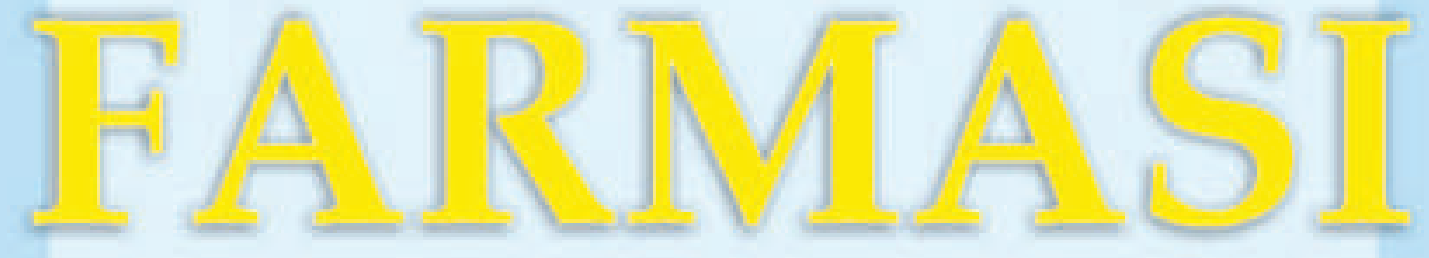

(Scientific Journal of Pharmacy) 
JURNAL ILMIAH FARMASI

(SCIENTIFIC JOURNAL OF PHARMACY)

PIMPINAN UMUM/ PENANGGUNG JAWAB

Dekan Fakultas Matematika dan Ilmu Pengetahuan Alam

Universitas Islam Indonesia

WAKIL PIMPINAN UMUM/ WAKIL PENANGGUNG JAWAB

Ketua Jurusan Farmasi FMIPA UII

\section{MITRA BESTARI}

1. Prof. Dr. Wiryatun Lestariana, Apt

2. Prof. Dr. Zullies Ikawati, Apt

3. Prof. Dr. Sudibyo Martono, Apt

4. Dr. Tedjo Yuwono, Apt

5. Prof. Dr. Dachriyanus, Apt

6. Prof. dr. Iwan Dwiprahasto, MMedSc, PhD

7. Prof. Dr. Lukman Hakim M.Sc., Apt

8. Prof. Dr. Achmad Fudholi, DEA, Apt

9. Prof. Dr. Ibnu Gholib Gandjar, DEA., Apt

$\begin{array}{ll} & \text { DEWAN EDITOR } \\ \text { Ketua } & \text { Saepudin, M.Si., Apt } \\ \text { Sekretaris } & \text { : Rochmy Istikharah, M.Sc., Apt. } \\ \text { Anggota } & \text { Vitarani Dwi Ananda Ningrum, M.Si., Apt } \\ & \text { Okti R. Mafruhah, MSc., Apt } \\ & \text { Dimas Adhi Pradana, MSc., Apt. } \\ & \text { Fithria DA. Suryanegara, MSc., Apt. } \\ & \text { Ari Wibowo, S.Farm., Apt } \\ & \text { Arba Pramudita Ramadani, MSc., Apt. } \\ & \text { Oktavia Indrati, S.Farm., Apt. }\end{array}$

Penerbit

Jurusan Farmasi Fakultas Matematika dan IImu Pengetahuan Alam Universitas Islam Indonesia

Alamat Penerbit Jurusan Farmasi FMIPA UII

Jl. Kaliurang Km. 14,4 Yogyakarta 55584

Telp. (0274) 896439 ext. 3047

Email: jif@uii.ac.id 


\title{
HEPATOTOKSISITAS PADA PENGOBATAN TUBERKULOSIS DI RSUD TANGERANG - INDONESIA
}

\author{
Vitarani Dwi Ananda Ningrum*, Arnia Megasari, Suci Hanifah \\ Jurusan Farmasi Fakultas MIPA, Universitas Islam Indonesia, Yogyakarta \\ *e-mail: vitarani_pharmacyUll@yahoo.com
}

\begin{abstract}
ABSTRAK
Reaksi obat yang tidak dikehendaki atau yang dikenal dengan ADR (Adverse Drug Reaction) merupakan respon pasien terhadap obat yang berbahaya dan tidak diharapkan yang terjadi pada penggunaan obat dengan dosis normal untuk tujuan profilaksis, diagnosis, terapi suatu penyakit, maupun modifikasi fungsi fisiologis. Obat yang telah diketahui dapat menimbulkan hepatotoksisitas atau kerusakan fungsi hepar adalah golongan antimikobakteri yang digunakan dalam pengobatan tuberkulosis (TB) paru. Pasien tuberkulosis harus menggunakan obat secara teratur sampai periode pengobatan selesai. Penggunaan OAT (Obat Antituberkulosis) secara terus menerus dalam jangka waktu yang cukup lama dapat menimbulkan ADR. Penelitian ini bertujuan untuk mengetahui kejadian hepatotoksisitas pada pasien tuberkulosis paru serta faktor-faktor yang mempengaruhi terjadinya hepatotoksisitas. Metode penelitian dilakukan dengan menggunakan rancangan studi cross sectional. Pasien yang dilibatkan dalam penelitian ini adalah pasien yang mendapatkan regimen terapi antituberkulosis di RSUD Tangerang pada periode 2006 - Februari 2009. Penilaian kejadian hepatotoksisitas berdasarkan adanya peningkatan kadar AST/ALT serum. Hasil penelitian dari 55 pasien menunjukkan bahwa kejadian hepatotoksik sebesar $38,2 \%$. Hasil uji statistik menggunakan analisis Regresi Binary Logistik dengan taraf kepercayaan 95\% menunjukkan jenis kelamin laki-laki dan penggunaan obat hepatotoksis lain memiliki pengaruh terhadap kejadian hepatotoksik. Selain itu terdapat faktor yang dapat mengurangi kejadian hepatotoksik diantaranya penghentian obat, penggantian obat, dan pemberian curcumin.
\end{abstract}

Kata kunci: antituberkulosis, faktor risiko, hepatotoksisitas, tuberkulosis paru

\section{ABSTRACT}

Adverse Drug Reactions (ADRs) are unwanted or unintended effects of medicines which occur at therapeutic doses used in human for prophylaxis, diagnosis, therapy of disease, or for modification of physiologic function. Drug-induced hepatotoxicity accounts for approximately $2 \%$ of cases of inpatient jaundice and the liver is involved in $3-10 \%$ of all adverse drug reactions. Drug induced hepatotoxicity that already known is antibiotic used for tuberculosis treatment. The objective of the study was to know the incidence and risk factors of hepatotoxicity in tuberculosis treatment. The study used cross sectional design carried out retrospectively to limited population, i.e. all patients with pulmonary tuberculosis at Tangerang General Hospital - Indonesia during 2006 - February 2009. Data were obtained from observation of medical record of patients who received regimen of antituberculosis. The assessment of hepatoxitoxicity was measured by increasing concentration serum AST/ALT. In Tangerang General Hospital, 2.137 patients were diagnosed pulmonary tuberculosis. As many as 55 inclusion cases showed that the incidence of hepatotoxicity was $38,2 \%$. According to regression Binary Logistics analysis with significance level $95 \%$ confidence showed that man and other hepatotoxicity drugs administration influence incidence of hepatotoxicity.

Keywords: hepatotoxicity, pulmonary tuberculosis, risk factors, tuberculosis treatment 


\title{
HEPATOTOKSISITAS PADA PENGOBATAN TUBERKULOSIS DI RSUD TANGERANG - INDONESIA
}

\author{
Vitarani Dwi Ananda Ningrum*, Arnia Megasari, Suci Hanifah \\ Jurusan Farmasi Fakultas MIPA, Universitas Islam Indonesia, Yogyakarta \\ "e-mail: vitarani_pharmacyUII@yahoo.com
}

\begin{abstract}
ABSTRAK
Reaksi obat yang tidak dikehendaki atau yang dikenal dengan ADR (Adverse Drug Reaction) merupakan respon pasien terhadap obat yang berbahaya dan tidak diharapkan yang terjadi pada penggunaan obat dengan dosis normal untuk tujuan profilaksis, diagnosis, terapi suatu penyakit, maupun modifikasi fungsi fisiologis. Obat yang telah diketahui dapat menimbulkan hepatotoksisitas atau kerusakan fungsi hepar adalah golongan antimikobakteri yang digunakan dalam pengobatan tuberkulosis (TB) paru. Pasien tuberkulosis harus menggunakan obat secara teratur sampai periode pengobatan selesai. Penggunaan OAT (Obat Antituberkulosis) secara terus menerus dalam jangka waktu yang cukup lama dapat menimbulkan ADR. Penelitian ini bertujuan untuk mengetahui kejadian hepatotoksisitas pada pasien tuberkulosis paru serta faktor-faktor yang mempengaruhi terjadinya hepatotoksisitas. Metode penelitian dilakukan dengan menggunakan rancangan studi cross sectional. Pasien yang dilibatkan dalam penelitian ini adalah pasien yang mendapatkan regimen terapi antituberkulosis di RSUD Tangerang pada periode-2006 Februari 2009. Penilaian kejadian hepatotoksisitas berdasarkan adanya peningkatan kadar AST/ALT serum. Hasil penelitian dari 55 pasien menunjukkan bahwa kejadian hepatotoksik sebesar $38,2 \%$. Hasil uji statistik menggunakan analisis Regresi Binary Logistik dengan taraf kepercayaan $95 \%$ menunjukkan jenis kelamin laki-laki dan penggunaan obat hepatotoksis lain memiliki pengaruh terhadap kejadian hepatotoksik. Selain itu terdapat faktor yang dapat mengurangi kejadian hepatotoksik diantaranya penghentian obat, penggantian obat, dan pemberian curcumin.
\end{abstract}

Kata kunci: antituberkulosis, faktor risiko, hepatotoksisitas, tuberkulosis paru

\begin{abstract}
Adverse Drug Reactions (ADRs) are unwanted or unintended effects of medicines which occur at therapeutic doses used in human for prophylaxis, diagnosis, therapy of disease, or for modification of physiologic function. Drug-induced hepatotoxicity accounts for approximately $2 \%$ of cases of inpatient jaundice and the liver is involved in $3-10 \%$ of all adverse drug reactions. Drug induced hepatotoxicity that already known is antibiotic used for tuberculosis treatment. The objective of the study was to know the incidence and risk factors of hepatotoxicity in tuberculosis treatment. The study used cross sectional design carried out retrospectively to limited population, i.e. all patients with pulmonary tuberculosis at Tangerang General Hospital - Indonesia during 2006 - February 2009. Data were obtained from observation of medical record of patients who received regimen of antituberculosis. The assessment of hepatoxitoxicity was measured by increasing concentration serum AST/ALT. In Tangerang General Hospital, 2.137 patients were diagnosed pulmonary tuberculosis. As many as $\mathbf{5 5}$ inclusion cases showed that the incidence of hepatotoxicity was $38,2 \%$. According to regression Binary Logistics analysis with significance level $95 \%$ confidence showed that man and other hepatotoxicity drugs administration influence incidence of hepatotoxicity.
\end{abstract}

Keywords : hepatotoxicity, pulmonary tuberculosis, risk factors, tuberculosis treatment 


\section{PENDAHULUAN}

Penggunaan obat dapat memberikan efek terapeutik yang menguntungkan karena dapat memperpanjang atau memperbaiki kualitas hidup seseorang. Obat juga memiliki potensi untuk menimbulkan reaksi yang tidak dikehendaki. Reaksi obat yang tidak dikehendaki merupakan respon suatu obat yang berbahaya dan tidak diharapkan yang terjadi pada penggunaan obat dengan dosis normal untuk tujuan profilaksis, diagnosis, terapi suatu penyakit, maupun modifikasi fungsi fisiologis. ADR dapat menjadi penyebab morbiditas dan mortilitas yang substansial dengan estimasi kejadian yang bervariasi (Lee, 2001). Dari sekian banyak ADR yang terjadi, 5,1\% nya adalah ADR yang bersifat serius. Prevalensi ini dapat meningkat seiring dengan bertambahnya usia yaitu mencapai 9,8\% (Hooft et al., 2008).

Berbagai dampak negatif yang ditimbulkan oleh kejadian ADR antara lain menyebabkan kecacatan dan kelainan kongenital serta menyebabkan pasien dirawat di rumah sakit dengan persentase sebesar $24 \%$, bahkan pada pasien geriatri mencapai $88 \%$ (Beijer and De Blaey, 2002). Dampak lain diantaranya dapat menyebabkan pasien lebih lama dirawat di rumah sakit bahkan dapat mengancam nyawa pasien serta menimbulkan kematian (Lee, 2001). Salah satu efek yang berbahaya dan tidak diharapkan akibat penggunaan obat adalah berupa kerusakan fungsi hepar atau hepatotoksisitas.

Hepatotoksisitas dapat didefinisikan sebagai kerusakan hepar yang disebabkan oleh obat dan bahan-bahan kimia. ADR berupa kerusakan hepar ditunjukkan dengan tes biokimia termasuk aspartat serum (AST) dan alanin aminotransferase (ALT), serum alkalin fosfatase (ALP), gamma glutamyl trensferase (GGT), atau bilirubin yang meningkat lebih dari dua kali kadar normalnya. Kerusakan hepar dapat berbeda-beda dari struktur non spesifik dan perubahan fungsional menjadi gagal hepar akut atau sirosis (Koda-Kimble et al., 2005). Beberapa obat yang telah diketahui dapat menimbulkan ADR berupa kerusakan fungsi hepar atau hepatotoksisitas adalah golongan antimikobakteri yang digunakan dalam pengobatan tuberkulosis (TB), yaitu pada penggunaan rifampisin-pirazinamid (Lee ot al., 2002; Lee et al., 2003; Hest et al., 2004).

Di Indonesia, TB masih merupakan masalah utama kesehatan masyarakat. Jumlah pasien TB di Indonesia merupakan k 33 terbanyak di dunia setelah India dan Cina dengan jumlah pasien sekitar 10\% dari total jumlah pasien TB di dunia. Tahun 1995, hasil Survei Kesehatan Rumah Tangga (SKRT) menunjukkan bahwa penyakit TB merupakan penyebab kematian nomor tiga setelah penyakit kardiovaskuler dan penyakit saluran pernafasan. Kejadian ini terjadi pada semua kelompok usia, dan nomor satu dari golongan penyakit infeksi (Depkes, 2007).

Rumah Sakit Umum (RSU) Tangerang merupakan rumah sakit rujukan dari daerah Tangerang dan sekitarnya bagi pasien tuberkulosis. Tuberkulosis menempati urutan pertama dari segi jumlah pasien yang dirawat di rumah sakit ini, yaitu mencapai tiga ribu orang per tahun karena Tangerang merupakan daerah endemik tuberkulosis (Anonim, 2009; Dini, 2009). Selain itu, instalasi rawat inap di rumah sakit ini memiliki prosedur tetap yang berupa pemeriksaan darah lengkap ketika pasien masuk rumah sakit yang meliputi pemeriksaan ALT dan AST. Prosedur ini yang tidak dilakukan di Balai Pengobatan Penyakit Paru-Paru (BP4) setempat sehingga diharapkan dapat diperoleh jumlah pasien yang cukup banyak yang memenuhi kriteria inklusi dan eksklusi. 
Pasien tuberkulosis harus menggunakan obat secara teratur sampai periode pengobatan selesai. Penggunaan regimen OAT (Obat Antituberkulosis) secara terus menerus selama jangka waktu yang cukup lama (2 sampai 9 bulan) dapat menimbulkan reaksi obat yang tidak dikehendaki. Hal ini mendorong dilakukannya penelitian yang bertujuan untuk mengetahui kejadian hepatotoksisitas pada penggunaan antituberkulosis serta faktor-faktor yang mempengaruhi terjadinya hepatotoksisitas.

\section{METODE PENELITIAN}

Penelitian dilakukan secara retrospektif menggunakan rancangan studi cross sectional dengan menggunakan data rekam medis pasien tuberkulosis paru yang menggunakan regimen obat antituberkulosis. Penelitian ini melibatkan pasien yang menjalani rawat jalan maupun rawat inap selama periode tahun 2006 hingga Februari 2009. Kriteria inklusi yang ditetapkan dalam penelitian ini yaitu pasien dengan usia $\geq 16$ tahun dan pasien yang disertai pemeriksaan AST/ALT minimal 2 (dua) kali. Penilaian kejadian hepatotoksisitas berdasarkan adanya penurunan fungsi hepar yang ditandai dengan peningkatan kadar serum AST dan ALT relatif sampai batas atas normal. Peningkatan kadar serum ALT harus lebih tinggi dibandingkan dengan AST. Kriteria eksklusi dalam penelitian ini adalah pasien dengan penyakit penyerta berupa kerusakan hati dan pasien yang tidak menyertakan hasil pemeriksaan AST dan ALT maupun obat antituberkulosis yang digunakan.

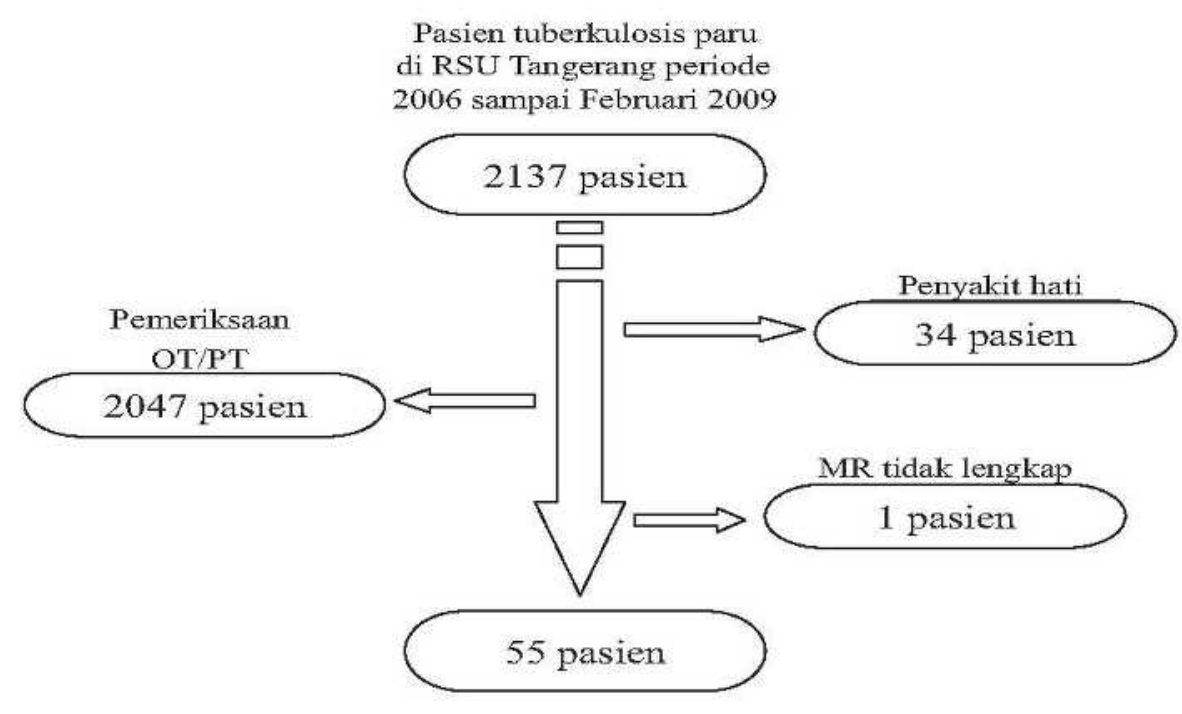

Gambar 1. Jumlah pasien yang dilibatkan dalam penelitian ini

Data yang diperoleh dijabarkan dalam bentuk tabel dengan tujuan untuk memperoleh gambaran mengenai karakteristik pasien, persentase kasus terjadinya hepatotoksisitas, serta manifestasi klinis kejadian hepatotoksisitas. Selanjutnya dilakukan analisis Regresi Binary Logistik 
dengan taraf kepercayaan $95 \%$, dengan tujuan untuk memperoleh gambaran mengenal faktorfaktor yang mempengaruhi kejadian hepatotoksisitas.

\section{HASIL DAN PEMBAHASAN}

Hasil penelitian menunjukkan bahwa penyakit tuberkulosis dialami oleh sebanyak $69 \%$ pasien laki-laki dan selebihnya dialami oleh pasien perempuan. Hal ini dapat dikaitkan dengan kebiasaan laki-laki yaitu merokok sehingga tuberkulosis banyak terjadi pada laki-laki. Berdasarkan analisis data survei prevalensi yang dilaporkan oleh Puslitbangkes (2006) bahwa paparan tembakau baik secara aktif maupun pasif meningkatkan resiko timbulnya penyakit tuberkulosis. Data dari Litbangkes menunjukkan bahwa mereka yang merokok (termasuk mereka yang masih merokok saat ini dan yang telah berhenti merokok) mempunyai resiko menjadi sakit tuberkulosis 3 kali lebih tinggi dibandingkan dengan mereka yang tidak merokok. Penelitian yang dilaporkan oleh Gajalakshmi (2003) menunjukkan bahwa $50 \%$ kematian akibat tuberkulosis berhubungan dengan kebiasaan merokok pada pria dewasa. Sebagian besar pasien tuberkulosis paru dalam penelitian ini berusia antara 26 - 35 tahun $(34,5 \%)$. Hal ini sesuai dengan Pedoman Nasional Penanggulangan Tuberkulosis yaitu sekitar $75 \%$ pasien tuberkulosis adalah kelompok usia yang paling produktif secara ekonomis yaitu 15 - 50 tahun (Depkes, 2007).

Kasus tuberkulosis paru tertinggi pada penelitian ini merupakan kasus baru yaitu pasien yang belum pernah diobati dengan OAT atau sudah pernah menelan OAT kurang dari satu bulan (4 minggu) sebanyak $70,9 \%$. Sebanyak $74,5 \%$ pasien tuberkulosis dalam penelitian ini mendapatkan terapi kategori 1 yaitu 2(HRZE)/4(HR)3. Berdasarkan Tabel 1 dapat diketahui bahwa persentase terbesar adalah pasien tuberkulosis yang tidak disertai dengan penyakit penyerta $(60 \%)$. Berdasarkan penelitian yang dilaporkan oleh Misnadiarly (2002) penyakit penyerta yang berupa diabetes, tuberkulosis ekstraparu, arterio sklerosis, sirosis hepajitis, asma dan bronkiektasis sebanyak $61,5 \%$ ditemukan sebagai penyakit primer, dan $38,5 \%$ sebagai penyakit sekunder. Pada penelitian ini yang termasuk dalam penyakit primer antara lain asma, pneumonia, ISPA, diabetes, dan diare sebanyak $9,1 \%$, sedangkan penyakit sekunder terjadi pada $31 \%$ yang meliputi efusi pleura, bronkhitis, asma, tuberkulosis kelenjar, dan diabetes melitus. 
Tabal 1. Karakteristik umum pasien tuberioulosis paru berdasarkan jenis kelamin dan usia dI RSU Tangerang tahun 2006 - Fobruari 2009

\begin{tabular}{|c|c|c|c|}
\hline Karakteristik & Kategori & $\begin{array}{l}\text { Jumilah } \\
\text { Pasien }\end{array}$ & $\begin{array}{c}\text { Persentase * } \\
\quad(n=55)\end{array}$ \\
\hline \multirow[t]{2}{*}{ Jenis kalarnin } & 1. Laki-lakd & 38 & $69,0 \%$ \\
\hline & 2. Perempuan & 17 & $31,0 \%$ \\
\hline \multirow[t]{6}{*}{ Umur } & 1. $16-25$ tahun & 4 & $7,3 \%$ \\
\hline & 2. $26-35$ tahun & 19 & $34,5 \%$ \\
\hline & 3. $36-45$ tahun & 11 & $20,0 \%$ \\
\hline & 4. $46-55$ tahun & 12 & $21,8 \%$ \\
\hline & 5. $56-65$ tahun & 5 & $9,1 \%$ \\
\hline & 6. $>65$ tahun & 4 & $7,3 \%$ \\
\hline \multirow[t]{4}{*}{ Jenis TB } & 1. Kasus baru & 39 & $70,9 \%$ \\
\hline & 2. Kasus ralaps & 12 & $21,8 \%$ \\
\hline & 3. Kasus setelah putus obat & 1 & $1,8 \%$ \\
\hline & 4. Kasus lain & 3 & $5,5 \%$ \\
\hline \multirow[t]{3}{*}{ Jenis terapi } & 1. Kategari 1 & 41 & $74,5 \%$ \\
\hline & 2. Kategori 2 & 10 & $18,2 \%$ \\
\hline & 3. $\mathrm{RHZ}$ & 4 & $7,3 \%$ \\
\hline \multirow[t]{3}{*}{ Penyakit peryyerta } & Penyakit primer & 5 & $9,1 \%$ \\
\hline & Penyakit sekunder & 17 & $31,0 \%$ \\
\hline & 3. Tanpa penyakit penyerta & 33 & $60.0 \%$ \\
\hline
\end{tabular}
kejadian hepatotolesik.

Berdasarkan hasil yang diperoleh dalam penelitian ini (Tabel 2), dar 55 pesien terdapat 21 pasien diantaranya mengalami kejadian hepatotoksik $(38,2 \%)$. Sebanyak $68,7 \%$ kejadian hepatotoksik adalah pada grade 1, yaitu kenaikan kadar ALT melebihi batas atas normalnya (Upper Limit of Normal, ULN) sampal 2,5 kall ULN atau dalam rontang kadar 41 - 143,5 uniutiter. Pasien yang mengalami peningkatan ULN 2,6 sampai 5 kall pada grade 2 sebanyak $14,3 \%$, sedangkan sisanya adalah grade 3 dengan peningkatan ULN 5 sampai 20 kali sebanyak $19 \%$. Penelitian yang dilaporkan oleh Lee et al. (2002) kejadian hepatotoksik terjadi pada grade 3 maupun 4, sedangkan peneitian yang dilaporkan oleh Lee et al (2003) dan Hest et al. (2004) hanya terjadi pada grade 4 saja dengan insidensi kurang dari $10 \%$.

Tabol 2. Klasiflikasi tingkat keparahan hepatotoksik pasien tuberkulosis pan di RSU Tangerang tahun 2006 - Fobruar 2009

\begin{tabular}{lc}
\hline \multicolumn{1}{c}{ Grade (Kadar ALT) } & Jumlah Pasien (Persentase* $n=21)$ \\
\hline 1. Grade 1 $(-U L N-143,5)$ & $14(66,7)$ \\
2. Grade 2 $(143,5-246)$ & $3(14,3)$ \\
3. Grade 3 $(246-861)$ & $4(19,0)$ \\
4. Grade 4 ( 8861$)$ & - \\
\hline Persertase dihitung dari jumlah iotal pasien yang mengalami kejadian hepatotoksik.
\end{tabular}

Identfikasi gejala klinis merupakan salah satu hal yang penting dalarn menegakkan diagnosis hepatotoksisitas. Jenis kerusakan hepar yang ditimbulkan oleh OAT seperti isoniazid, rifampisin, dan pirazinamid dapat benpa nekrosis hepatoseluler akut dengan manifestasi klinis berupa fatlgut, anoreksia, mual, dan jaundice. Apabila nekrosis yang ditimbulkan lebih besar dapat terjadi jaundice yang berat, coagulopathy, ascites, hepatic encephalopathy, koma, bahikan kematian (KodaKimble of al., 2005; Lee, 2001). Secara teortis kadar ALT meningkat beberapa hari sebelum kejadian 
Ikterus (Kee, 2007), namun dalam peneitian ini kejadian Ikterus tidak dapat diketahul seiring dengan peningkatan ALT, sehingga manifestasi kinis yang berupa ikterus yang menyertai kejadian hepatotoksisitas tidak dapat dijadkan parameter dalam menentukan kejadian hepatotoksik. Solain parameter ALT, hepatotoksisitas dapat teramati dengan melihat data fisik berupa gejala kinis yang merupukan manifestasi kejadian hepatotoksik. Manifestasi klinik hepatotoksisitas yang berupa gejala kilinis disalikan pada Tabel 3.

Tabel 3. Manifestasi kilinik hepatotoksik berupa gejala kilins pada pasien tuberkulosis paru di RSU Tangerang tahun 2006 - Februari 2009

\begin{tabular}{lcc}
\hline \multicolumn{1}{c}{ Gejala Kin/s } & Grade & Jumlah Pasien (Persentase" $n=21$ ) \\
\hline Mual & 1 & $2(9,6)$ \\
Mual dan muntah & 2 & $9(4,7)$ \\
Mual, muntah, mata kuning & 1 & $2(9,6)$ \\
Tidak ada keterangan & 2 & $1(4,7)$ \\
& 1 & $10(47,6)$ \\
& 2 & $1(4,7)$ \\
& 3 & $4(19,1)$ \\
\hline
\end{tabular}

"Porsantase dihitung dart jurriah total pasion yang mangalami kejadian hopatotoksik.

Menunut Bayupumama (2006) gejala hepatotoksik adalah berupa malaise dan likterua. Dalam peneilían ini gejala yang tercatat berupa mual, yang terjadi pada $9,6 \%$ pasion hepatotoksik grade 1 dan $4,7 \%$ pasien hepatotoksikgrade 2, gejala mual muntah terjadi pada pasien grade 1 dengan persentase sebesar $9,6 \%$. Mual, muntah dan iktents terjadi pada $4,7 \%$ pasien hepatotoksik grado 2. Pasien yang mengatami kejadian hepalotoksik can tidak disertai keterangan gejala klinis yang ditimbulkan oleh OAT pada pasien grade 1 sebesar $47,6 \%$, pada pasien grade 2 sebesar $4,7 \%$, dan pada pasien grade 3 sebesar $19,1 \%$.

Identifikasi faktor-faktor yang dapat mempengaruhi kejadlan hepatotoksik penting untuk diketahul. Pengetahuan tentang hal tersebut dapat digunakan sobagai pertimbangan mendasar untuk dilakukan terapl pencegahan sehingga kejadian hepatotoksisitas akibat pemberian OAT dapat dicegah lebih dini. Identifikasi faktor-faktor yang mempengaruhi hepatotoksisitas yaitu dengan menggunakan uj Regresi Binary Logistik. Variabel tergantung yang ditetapkan adalah status pasien yaitu berupa hepatotoksik atau tidak dan variabel bebas antara lain jenis kelamin, usia, jenis tuberkulosis, Jenis terapl, durasi terapl, status alkoholik, riwayat penyakit sebeiumnya, serta obat lain. Hasil uji regresi linier berganda didapatkan bahwa dar semua variabel bebas yang memiliki pengaruh terhadap kejadian hepatotoksik secara statistk adalah jenis kelamin ( $P=0,009)$ dan pongaunaan obat penginduksi hopatotoksk lain $(P=0,047)$. 
Tabol 4. Karakteristik pesien tuberkuiosis paru berdasarkan faktor resiko di RSU Tangerang tahun 2006 - Fobruarl 2009

\begin{tabular}{|c|c|c|c|c|c|}
\hline $\begin{array}{l}\text { Faktor } \\
\text { Resiko }\end{array}$ & Kategor & Hepatotoksik & $\begin{array}{c}\text { Thdak } \\
\text { Hegatoloksik }\end{array}$ & $\begin{array}{l}\text { Jumlah } \\
\text { Pasien }\end{array}$ & $\begin{array}{l}P(s i g] \text { lika } \\
\rho<0,05)\end{array}$ \\
\hline Jentis & Lakd-Lakd & 19 & 20 & 39 & 0,009 \\
\hline Kelamin & Perempuan & 2 & 15 & 17 & \\
\hline \multirow[t]{6}{*}{ Umur } & $16-25$ & 1 & 3 & 4 & 0,244 \\
\hline & $26-35$ & 8 & 11 & 18 & \\
\hline & $38-45$ & 4 & 7 & 11 & \\
\hline & 46.55 & 7 & 6 & 13 & \\
\hline & $56-65$ & - & 5 & 5 & \\
\hline & $>65$ & 1 & 3 & 4 & \\
\hline \multirow[t]{4}{*}{ Jenis TB } & Kasus baru & 17 & 22 & 39 & 0,093 \\
\hline & Kasus relap5 & 4 & 8 & 12 & \\
\hline & Kasus selelah putus & - & 1 & 1 & \\
\hline & Kasus lain & $=$ & 4 & 4 & \\
\hline Jenis & Kategori I & 19 & 22 & 41 & 0,368 \\
\hline \multirow[t]{2}{*}{ Terapi } & Kategori II & 2 & 8 & 10 & \\
\hline & $\mathrm{RHZ}$ & . & 4 & 4 & \\
\hline Durasi & $<2$ bulan & 13 & 11 & 24 & 0,295 \\
\hline \multirow[t]{3}{*}{ Terapi } & $2-6$ bulan & 5 & 15 & 20 & \\
\hline & $8-9$ bulan & 3 & 6 & 9 & \\
\hline & Tidak diketahui & - & 3 & 3 & \\
\hline \multirow[t]{3}{*}{ Alkohol } & Narkoba & 1 & 1 & 2 & 0,876 \\
\hline & Perokok & 1 & $\therefore$ & 1 & \\
\hline & Tidak ada & 19 & 34 & 53 & \\
\hline Riwayat & Pemalasan & 1 & 6 & 7 & 0,647 \\
\hline Penyakit & Endokrin, & 2 & 1 & 3 & \\
\hline Sebelum & metabolsme & 2 & - & 2 & \\
\hline \multirow[t]{2}{*}{ nya } & Gastrointestinal & 5 & 7 & 12 & \\
\hline & $\begin{array}{l}\text { Lain - tain } \\
\text { Tanpa panyakit }\end{array}$ & 11 & 21 & 32 & \\
\hline Obat & Hepatotoksik & B & 16 & 24 & 0,047 \\
\hline \multirow[t]{3}{*}{ Lain } & Tidak Hepalotoksik & 5 & 13 & 18 & \\
\hline & Tidak ada & 4 & 6 & 10 & \\
\hline & Tidak diketahul & 4 & . & 4 & \\
\hline
\end{tabular}

Upaya untuk menangani kejadian hepatotoksik yaitu dengan penghentian maupun penggentan regimen OAT telah dilakukan oleh tim madis RSU Tangerang. Selain Itu dilakukan upaya pencegahan hepatotoksik dengan memberikan hepatoprotoktor seperti kurkumin, namun tidak semua pasien mendapatkan upaya penanganan maupun pencegahan hepatotoksik.

Karakteristik pesien hepatotoksik yang mengalami perbakikan atau penurunsn ALT sampai kisaran nomal disajikan dalam Tabel 5.

Tabel 5. Upaya pengatasan kejadian hepatotoksk pada pasien tuberkulosis paru di RSU Tangerang tahun 2006-Februari 2009

\begin{tabular}{ccccc}
\hline $\begin{array}{c}\text { Tindakan } \\
\text { Perbaikan }\end{array}$ & Grade & Regimen & $\begin{array}{c}\text { Jumlah } \\
\text { Pasian }\end{array}$ & $\begin{array}{c}\text { Jumlah Pasien yang Mengalami } \\
\text { Perbaikan (\%) }\end{array}$ \\
\hline Penghentian obat & 3 & - & 2 & $2(100)$ \\
Penggantian obat & 1 & Katagori 2 & 1 & $1(33,3)$ \\
& 2 & E, S, Otx & 1 & \\
& 3 & E, S, Ofx & 1 & $1(33,3)$ \\
\hline
\end{tabular}

- Parsantase dihitung deri jumlah pasinen yang mengalami penghertian maupun panggantian obat. 
Berdasarkan Tabel 5 , terdapat 2 pasien yang mengalami penghentian regimen OAT karena mengalami hepatotoksik pada grade 3 dan semuanya mengalami perbaikan. Pasien lain yang mengalami hepatotoksik padagrade 3 mengalami penggantian regimen OAT dengan ethambutol, streptomisin, dan ofloksasin namun hanya 1 pasien saja yang mengalami perbaikan. Penggantian regimen OAT juga dilakukan pada pasien yang mengalami hepatotoksik pada grado 1 dengan kategori 2, yaitu RHE dan mengalami perbaikan.

Secara umum penanganan hepatotoksisitas dilakukan dengan menghentikan penggunaan obat yang hepatotoksik (Lee, 2001). Pada kasus hepatotoksik grade 1 dan 2, penggunaan OAT dapat dilanjutkan setelah kejadian hepatotoksik dan dilakukan pemeriksaan ALT dan AST 2 minggu. Hal ini dilakukan dengan pertimbangan bahwa seperti halnya sel-sel lain dalam tubuh, hepatosit bila mengalami trauma baik yang bersifat fisik maupun kimiawi maka akan segera berupaya melakukan regenerasi (Adhvaryu et al., 2008; Prihatni $\theta t$ al., 2005). Pada kasus grade 3 dan grade 4 penggunaan OAT dihentikan hingga kadar ALT kembali normal (Adhvaryu et al., 2008).

Berdasarkan CDC (2003) penggunaan OAT dihentikan apabila peningkatan ALT melebihi 3 kali ULN (Upper Limit of Norma) dengan gejala atau peningkatan ALT melebihi 5 kali ULN tanpa gejala. Gejala yang dimaksud adalah peningkatan kadar bilirubin akibat peningkatan kadar enzim transaminase, yang merupakan marker (penanda) kejadian hepatotoksisitas.

Apabila kejadian hepatotoksisitas yang dialami pasien bersifat mild (sedang) maka terapi OAT ditunda sampai kadar ALT kurang dari 2 kali ULN dan tidak tampak gejala hepatotoksik. Selanjutnya dimulai kembali terapi menggunakan HRZE selama 1 minggu untuk mengetahui apakah kejadian hepatotoksik bersifat potensial atau tidak. Jika pasien berpotensi mengalami hepatotoksik yang severe (berat), maka pirazinamid dihilangkan dari regimen tersebut dan durasi terapi diperpanjang sampai 9 bulan apabila isoniazid dan rifampisin dapat ditoleransi dengan baik oleh pasien. Apabila kejadian hepatotoksisitas yang dialami pasien bersifat severe (berat), maka dilakukan penggantian regimen yang tidak hepatotoksik seperti streptomisin, ethambutol, dan moksifloksasin (CDC, 2003).

Selain tindakan penghentian dan penggantian OAT, tindakan lain yang dilakukan oleh tim medis di RSU Tangerang adalah dengan meresepkan kurkumin kepada pasien tuberkulosis sebagai upaya pencegahan maupun penanganan kejadian hepatotoksik. Karakteristik pasien hepatotoksik yang mendapatkan kurkumin pada penelitian ini disajikan pada Tabel 6. 
Tabel 6. Pemberian kuricumin pada pasken yang mengalami hepatotoksik dl RSU Tangerang tahun 2006 - Fobruari 2009

\begin{tabular}{|c|c|c|c|c|c|c|}
\hline $\begin{array}{l}\text { Kondisi } \\
\text { Pasien } \\
\end{array}$ & Grade & Frekuensl & $\begin{array}{l}\text { Duragi } \\
\text { (hari) }\end{array}$ & $\begin{array}{l}\text { Jumlah } \\
\text { Pasion }\end{array}$ & $\begin{array}{l}\text { Jumlah Paslen yang } \\
\text { Mongalami Porbaikan }\end{array}$ & Ket \\
\hline \multirow{8}{*}{ Hepatotoksik } & 1 & $2 \times 1$ & 30 & 1 & 1 & $\dot{*}$ \\
\hline & & $3 \times 1$ & 14 & 1 & - & + RHE \\
\hline & & $3 \times 1$ & 60 & 1 & - & + \\
\hline & & $3 \times 1$ & 7 & 1 & 1 & * \\
\hline & 2 & $3 \times 1$ & 12 & 1 & - & • \\
\hline & & $3 \times 2$ & 8 & 1 & - & $\bullet$ \\
\hline & 3 & $3 \times 1$ & 7 & 1 & 1 & +ESOF \\
\hline & & $3 \times 2$ & 15 & 1 & 1 & $\underset{\text { stop }}{x}$ \\
\hline
\end{tabular}

APasien yang tidak mandapatkan ponggantian rogiman OAT maupun pengharitian OAT

Tujuan penggunaan kurkumin pada pasien yang mengalami hepatotoksax pada grade 1 , grade 2, maupun grade 3 adalah sebagai upaya pengatasan kejadian hepatotoksik. Kurkumin sebagai salah satu obat tradisional yang dapat memelihara fungsi hat ternyata bermanfaat sebagal hepatoprotektor. Seperti terlihat pada Tabel 6 sebanyak $50 \%$ pasien yang mengalami hepatotoksik mengalami perbaikan hingga kadar AL.T-nya mencapai kisaran normal. Pasien yang mengalami hepatotoksik pada grade 1 selain diberikan kurkumin juga mendapatkan penggantian regirnen OAT, namun kadar ALT nya totap belum normal. Hal ini dapat dlikarenakan dosis yang kurang atau pasien juga menggunakan obat lain yang beraifat hepatotoksk. Begitu pula pada pasian yang mengaiami hepatotoksk pada grado 2. Ponggunaan kurkumin ternyata oukup bermantaat bagi pasien yang mengalami hepatotoksik grade 3 , tatapi dengan catatan harus dilakukan penggantian regimen OAT yang tidak hepatotoksik atau dengan penghentian OAT. Karakteristik pasien yang mendapatkan kurkumin bersamaan dengan pemberlan OAT dapat dillhat pada Tabel 7.

Tabel 7. Hasil pemeriksaan fungsi hatl pada pasien tuberkulosis paru yang mendapatkan kurkumin sebagal terapi pencegahan hepatotoksik di RSU Tangerang tahun 2006 - Februari 2009

\begin{tabular}{ccccc}
\hline Pengquanan Kurkamin & Frekuensi & Durasi (hari) & ALT Sebeium & ALT Sesudah \\
\hline & $2 \times 1$ & 15 & 12 & 22 \\
& $2 \times 1$ & 15 & 16 & 23 \\
& $2 \times 1$ & 53 & & 10 \\
Bersamaan dengan & $2 \times 1$ & 8 & 12 & 9 \\
OAT & $2 \times 1$ & 7 & 11 & 20 \\
& $2 \times 1$ & 15 & 18 & 28 \\
& $2 \times 1$ & 19 & 16 & 24 \\
& $2 \times 1$ & 10 & 15 & 25 \\
Rata-rata & $3 \times 1$ & 10 & 19 & 10 \\
\hline & $2 \times 1$ & 1 & & 10 \\
& $2 \times 1$ & 16 & & 10 \\
\hline
\end{tabular}

Berdasarkan Tabel 7 sebanyak \& pasien yang tidak mengalami hepatotoksik ternyata telah mendapatkan kurkumin bersamaan dengan pemberian OAT sehingga semua pasien tidak 

